\title{
Total Body PET Imaging
}

Editors

RAMSEY D. BADAWI

JOEL S. KARP

LORENZO NARDO

AUSTIN R. PANTEL

\section{PET CLINICS}

www.pet.theclinics.com

Consulting Editor

ABASS ALAVI

January 2021 • Volume 16 - Number 1 